\title{
A Debate on Corporate Governance of Family Firms and Business Groups
}

\author{
Changmin LeE ${ }^{* *} \cdot$ Hong ChONG ChO ${ }^{* *}$ \\ AND HYOUNG-GOO KANG**
}

This article reviews corporate governance literature of family firms and business groups which is relevant to Korean conglomerates. We summarize major issues on corporate governance for Korean conglomerates and classify studies according to those issues: existence of controlling shareholder, deviation from the one share-one vote principle, family members' participation in management, succession of control to family members, and the relationship between financial and industrial capital within business groups. Existing literature shows that firms with controlling shareholders are common globally. While many factors related to corporate governance impact firm value, they create both positive and negative ramifications in a nuanced manner. Also, corporate governance endogenously emerges under different circumstances-law, degree of market development, or management-union relations across countries. Thus, there is no strict standard corporate governance system that can apply to all family business groups in different countries. Proper frameworks for policy makers and managers will arise only in the particular contexts in which family business groups operate.

Keywords: Corporate Governance, Family Firm, Business Group, Controlling Shareholder, One Share-One Vote Principle, Succession of Control

This work was supported by the National Research Foundation of Korea Grant funded by the Korean Government (NRF-2010-332-B00110).

* First Author, Assistant Professor. Department of Management, Kookmin University:

... E-mail: changmin74(a) yahoo.co.kr

Assistant Professor, Department of Economics, College of Business and Economics, Dankook University E-mail: hongcho@dankook.ac.kr

Corresponding Author, Assistant Professor, Department of Finance, Hanyang University School of Business: E-mail: hyoungkang@hanyang.ac.kr 


\section{INTRODUCTION}

F

amily-owned business groups have been an important topic in business.

For example, Korean chaebols (or family-owned conglomerates) have made a substantial impact on the domestic economy and have evolved into major global players. On the one hand, corporate governance literature has found that governance can influence firm value and social wolfare significantiy. However, much debate still remains in many areas of corporate governance. In particular, despite numerous studies about family firms and business groups, few describe key issues and there has yet to be a consensus reached about the subject. In this paper, we investigate what the core issues and findings are in the existing literature about family firms and business groups, and suggest managerial and policy implications with particular reference to chaebols.

A bulk of existing literature has conducted theoretical and empirical studies about corporate governance of family firms and business groups. For the purposes of this paper, family firms are those in which the founder and his or her family hold shares or are the members of the management or board of directors of the company in a narrow sense. They can also refer to firms in which the founder and his or her family are the controlling shareholders. A business group refers to a type of firm in which several independent companies are connected through shares or family relations. Two pioncering studies related to this topic include La Porta, Lopez-de-Silanes, and Shleifer (1999) and Anderson and Reeb (2003).

La Porta et al. (1999) analyze corporate governance of large companies in 27 developed countries and offer several findings. First, many have controlling shareholders and are controlled by a family and the state. In the study, a controlling shareholder refers to one who holds more than $10 \%$ of voting rights. Second, many firms deviate from the classic one share-one vote principle through pyramid structures or participation in management. Third, the controlling family significantly affects the management of a firm. Findings suggest that controlling family participation in management occurred in $75 \%$ of family firms in countries with good shareholder protection, while this level was $64 \%$ in countries with poor shareholder protection. The extent of shareholder protection is a legal issue. Corporate law or commercial law, for example, specifies the one share-one vote rule, shareholding ratios for opening general meeting of shareholders, or the possibility of class action. A country offers good shareholder protection if it guarantees a one share-one vote, has lower shareholding ratios required to summon extraordinary general meetings, and enables class action. Cross-shareholding is rare, except in Sweden and Germany.

Anderson and Reeb (2003) analyze the performance of U.S. family firms among S\&P 500 companies in 1992. For their study, family firms were defined as firms in which the founder and related family members own shares or are members 
of the board of directors. They found that one-third of S\&P 500 companies are family firms. While the family owned just around $18 \%$ of shares on average, family control and influence were much more powerful than indicated by the shareholding level alone. For instance, their voting rights for boards of directors were $150 \%$ greater than their cash-flow right. In addition to these findings, the study found that family firms tended to perform better than non-family firms.

The aforementioned studies triggered many follow-up studies centering on the following issues: (1) whether and what types (family, financial institutions, etc.) of controlling shareholders exist in each country, (2) what factors determine the types of controlling shareholders, (3) whether and to which degree controlling shareholders participate in management, (4) what performance or what advantages and disadvantages the various ownership and control structures generate, (5) what is the international pattern and distribution of family firms, corporate structure, and performance, (6) how succession of control within family firms occurs, and (7) what are the major characteristics of family business groups.

This line of literature has significant implications to chaebols because most chaebols are family business groups-as they show properties of both family firms and business groups. As such, the literature is very relevant to many important issues on the corporate governance of chaebols. Of course, there are corporate governance studies specific to Korean conglomerate issues such as Amsden (1989), Guillen (2000), Chang (2003), and Chang and Hong (2000, 2002), but we survey the previous literature more broadly to provide more implications.

First, there are debates about the patterns of controlling shareholders (ownership concentration) or control by the founder and family in chaebols. In general, dispersed ownership structures are considered more advanced. Family members may control companies only in developing countries. However, there is an argument that the firm should have a controlling shareholder. A controlling shareholder has positive influence on the market value of a firm since family members have larger incentives for monitoring management. See Shleifer and Vishny (1986), Admati, Pfleiderer, and Zechner (1994), Huddart (1993), Noe (1997), and Maug (1998). Also, there is no empirical evidence that family businesses are inefficient (Anderson and Reeb 2003; Villalonga and Amit 2006a, 2006b; Francisco PerezGonzalez 2006).

Second, managerial and regulatory issues include deviations from the one share-one vote principle, problems of the pyramid structure, mutual investment, and circular equity investment, among others. A controlling shareholder can exercise more control through a pyramid structure or circular equity investment than what shareholding itself implies. Such problems can generate conflicts of interest between controlling and minority shareholders, often referred to as tunneling (Johnson, La Porta, Lopez-de-Silanes, and Shleifer 2000; Bae, Kang, and Kim 2002; Bertrand, Mehta, and Mullainathan 2002; Campbell and Keys 2003; 
Joh 2003; La Porta, Lopez-de-Silanes, and Zamarripa 2003; Baek, Kang, and Lee 2006; Burkart and Lee 2007). For instance, when a controlling shareholder has a considerable amount of shares of company $A$ and controls $B$ through $A$, the controlling shareholder may redirect $B$ 's assets in favor of $A$. This sacrifices the interest of shareholders in $B$ on behalf of those in $A$, a type of moral hazard. In addition, mutual guarantee through circular equity investment or mutual investment (e.g., firm $A$ owns shares of firm $B$, while $B$ owns shares of $A$ as well) creates the problem of concentration of economic power. Tunneling is at odds with fair trade as well. According to the Economic Reform Reports 2008-5 from Solidarity for Economic Reform, among the top Korean 200 companies by asset size, 127 companies are subsidiaries of 40 conglomerates and constitute $63 \%$ of total assets and $70 \%$ of total revenue.

Several counterarguments, however, dispute such tunneling concerns. Some argue that risk sharing can lead to mutual investment or pyramidal structure in a business group (Kahnna and Yafeh 2005, 2007; Burkart and Lee 2007). Control through a pyramid structure or circular equity investment generates larger power to controlling shareholders versus control through pure shareholding. Such power can be effective in fighting against hostile takeovers (Berndt 2000; Pagano and Volpin 2005; Burkart and Lee 2007). For a case study on a Belgian corporate group, see Buysschaert, Deloof, and Jegers (2004).

Third, there are debates about whether controlling shareholders or professional managers should determine management. On the one hand, professional managers are likely to be more talented (Berle and Means 1932; Burkart, Panunzi, and Shleifer 2003). In addition, monitoring problems may arise if controlling shareholders directly manage a firm. Controlling shareholders have strong incentives to monitor the CEO. If controlling shareholders become the CEO, the one who can check managerial action best becomes the one who is in charge of the management. This is not only wasteful, but also creates further problems. As a controlling shareholder exercises powerful control by managing a firm directly, it can build trenches at the expense of checks and balances. On the other hand, risk of moral hazard by hired CEOs may decrease if controlling shareholders manage a firm directly. This can facilitate long-term investment (Jensen and Meckling 1976; Grossman and Hart 1988).

Fourth, chaebols can complicate the relationship between financial capital and industrial capital. One of the main functions of financial capital is to monitor industrial capital and management. Financial capital loses its independence and monitoring capabilities if financial capital and industrial capital are owned by a single conglomerate and become connected to each other via mutual investment and guarantees (Kane 1989; Kang and Stulz 1997; Morck and Nakamura 1999; Demirgüç-Kunt and Detraiache 2000; Gil-Díaz 2000; La Porta et al. 2003). On the other hand, financial capital may be able to better monitor its borrowers by collecting unique information about an industry and a firm upon exclusive 
relationship (Hoshi, Kashyap, and Scharfstein 1991; Rajan 1992; Aoki, Patrick and Sheard 1994). In addition, conflicts of interest may decrease if financial capital holds industrial capital. If a bank establishes a relationship with a company only through a loan, the possibility of conflicts of interest may arise between the bank (lenders) and shareholders. For instance, a positive NPV project with significant risk may be supported by shareholders but rejected by lenders because lenders do not share upside returns. As a result, increasing shareholdings by banks can solve such conflicts of interest (Kroszner and Strahan 2001).

Fifth, there has been much debate about the way in which the controlling family transfers management rights to the next generation. The selection of the $\mathrm{CEO}$ among family members can decrease the competence of the management board, thereby potentially affecting the firm's performance and market value (Morck, Stangeland, and Yeung 2000; Burkart, Panunzi, and Shleifer 2003). In contrast, some argue that family members can better manage companies by holding a long-term view and reducing agency cost between executives and shareholders (Jensen and Meckling 1976; Grossman and Hart 1988; Mueller and Philippon 2008).

Existing literature provides several insights about these five issues. First, firms with controlling shareholders are common globally, although governance structures exhibit country-specific variations depending on the law, degree of market development, or management-union relations. Families and financial institutions such as banks, insurance companies, and pension funds constitute most controlling shareholders as well. The rate of family (controlling shareholder) participation in management is nearly equal in the United States and Asia at $24.57 \%$.

Second, while most family firms deviate from the one share-one vote principle, its effect on firm performance is ambiguous. The proportion of firms owned and managed by family members is highest in Europe, while levels are similar in the United States and Asia. The impact of succession of control on the market value of a firm and performance depends on various conditions, showing mixed results.

Finally, business groups, especially family business groups, generally appear in developing countries. The internal market in a business group has been an important source of capital under weak external capital markets. Similarly, internal labor markets complement underdeveloped external labor markets in developing countries. Those historical circumstances result in complicated governance structures, such as pyramid structures or mutual investment. Risk sharing has been an important function of conglomerate groups in Japan, Korea, and Thailand as well.

With this in mind, the following sections investigate in greater detail corporate governance issues as related to chaebols from findings of existing literature. This generates implications on Korean conglomerates in the following areas: (1) ownership and control, (2) family firms, and (3) business groups. 


\section{OWNERSHIP AND CONTROL}

\section{Existence, Forms, and Management of Controlling Shareholders}

Gadhoum, Lang, and Young (2005) analyzed controlling shareholders of 3,607 U.S.-listed companies (both family and non-family firms) in 1996. They define controlling shateloider as a sharehoider with voting rights of more than $10 \%$. Table 1 shows the outcome. They find that $59.74 \%$ of U.S. firms have controlling shareholders compared to $79.72 \%$ in Asia and $86.28 \%$ in Europe. Although the rate for the United States is lower than those for Asia and Europe, a considerable number of U.S. firms were found to have controlling shareholders. In addition, the study found that $36.6 \%$ of U.S. firms are controlled by the family. While the rate of family firms decreased as the size of firms increased, family firms still constituted $20.36 \%$ of the top $20 \%$ of firms based on asset size. The proportion of U.S. firms controlled and managed by the family is $24.57 \%$. The family members are in the positions of CEO, honorary chairman, chairman or vice-chairman in these firms. In the United States, pension funds, mutual funds, and insurance companies, not banks, control $12.38 \%$ of firms.

Table 1. Controt.ling Shareholders in the United States. Eqrope, and Asia

\begin{tabular}{lccc}
\hline & United States & Asia & Europe \\
\hline Dispersed structure & $10.26 \%$ & $20.28 \%$ & $13.72 \%$ \\
\hline Firms with controlling shareholder & $59.74 \%$ & $79.72 \%$ & $86.28 \%$ \\
\hline Total & $100 \%$ & $100 \%$ & $100 \%$ \\
\hline Firms controlled by the family & $30.60 \%$ & $-15.05 \%$ & $55.87 \%$ \\
(Firms controlled and managed by the family) & $124.57 \%)$ & $(24.57 \%)$ & $(37.32 \%)$ \\
\hline Firms controlled by financial institutions & $16.33 \%$ & $17.80 \%$ & $18.34 \%$ \\
\hline Firms controlled by others & $12.81 \%$ & $16.87 \%$ & $12.07 \%$ \\
\hline Total Firms with controlling shareholder & $59.74 \%$ & $79.72 \%$ & $86.28 \%$ \\
\hline NOTE: Dispersed structure is the proportion of firms without a controlling shareholder. The controlling \\
shareholder is a shareholder with voting rights of more than $10 \%$.
\end{tabular}

On the one hand, findings concluded that there is powerful protection for minority shareholders by law. In fact, many studies argue that the shareholder protection law is a critical factor of corporate governance. But in practice, many firms are controlled by the family or by financial institutions. If there is powerful protection for minority shareholders by law, we should expect the private benefit of control to decrease. As a result, a dispersed ownership structure should become universal (La Porta et al. 1998; La Porta, Lopez-de-Silanes, Shleifer, and Vishny 2002; Fogel 2006). Gadhoum et al. (2005) also analyzed the ownership structure of five developed countries: the United States, Japan, Germany, France, and 
the UK (see Table 2). However, studies found the rate of family firms in the United States, $36.6 \%$, to be relatively high compared to other developed countries, with the exception of Germany.

Tabie 2. Comparison of Corporate Governance in 5 Developed Countries

\begin{tabular}{lccccc}
\hline & United Siates & japall & Germany & France & UK \\
\hline Dispersed structure & $44.26 \%$ & $42 \%$ & $3.6 \%$ & $6.2 \%$ & $22.59 \%$ \\
\hline Firms controlled by family & $36.6 \%$ & $13.1 \%$ & $37.26 \%$ & $34.3 \%$ & $25.27 \%$ \\
\hline $\begin{array}{l}\text { Firms controlled by financial } \\
\text { institution }\end{array}$ & $16.33 \%$ & $38.5 \%$ & $22.35 \%$ & $20.73 \%$ & $37.04 \%$ \\
\hline Firms controlled by others & $2.81 \%$ & $6.4 \%$ & $36.79 \%$ & $38.77 \%$ & $15.1 \%$ \\
\hline \multicolumn{1}{c}{ Total } & $100 \%$ & $100 \%$ & $100 \%$ & $100 \%$ & $100 \%$ \\
\hline
\end{tabular}

NOTE: Dispersed structure is the proportion of firms without a controlling shareholder. The controlling shareholder is a sharehoider with voting rights of more than $10 \%$.

From this perspective, it is difficult to explain such a high rate of family firms in the United States. Gadhoum et al. (2005) suggest one possibility. After assuming that a firm chooses the optimal governance structure (family control or financial institution control) to maximize shareholder value, the firm would compare the cost of tunneling by family members and a doubled agency cost made by a financial institution. When a financial institution controls a firm, the $\mathrm{CEO}$ of a financial institution has to monitor the CEO of a firm. An agent (CEO of a financial institution) monitors an agent (CEO of a firm), which might cause additional agency costs such as a cartel. If protection for shareholder rights is strong, tunneling problems are less likely to occur, suggesting that control by family members is less costly than control by financial institutions. Firm control by financial institution is rare in the United States, not only because of the Glass-Steagall Act which restricts banks from owning stocks, but also because of the choice of optimal structure under the given legal environment. This might be able to explain such a high rate of financial institutions' control in the UK. Normally, minority shareholder protection in the UK is considered as powerful as that of the United States. Nevertheless, since class action lawsuits are prohibited and because the loser has to pay for the winner's costs, minor shareholders are effectively discouraged from filing lawsuits. This suggests that minority shareholder protection in the UK is not as efficient as that in the United States. But whether this theory can explain high family firm ratios in Germany and France is doubtful, as Germany and France are considered to have weaker protection for minority shareholders versus the United States.

Faccio and Lang (2002) analyze corporate governance of large, medium, and 
small-sized companies in Europe, including both financial and non-financial institutions. They define a controlling shareholder as a shareholder with voting rights of more than $20 \%$. Their sample includes 5,232 firms from Austria, Belgium, Finland, France, Germany, Ireland, Italy, Norway, Portugal, Spain, Sweden, Switzerland, and the UK. They find that the proportion of dispersed structure is $36.93 \%$, and that family controlled firms is $44.29 \%$. The highest rate of dispersed structure is $63.08 \%$ in the UK and that of family controlled firms is $64.82 \%$ in France. In addition, they show that the proportion of dispersed structure in financial institutions is $39.92 \%$ and that of family controlled ones is $26.54 \%$ in the entire sample.

Claessens, Djankov, and Lang (2000) analyze corporate governance of East Asian firms. Their data set include 2,980 firms from Hong Kong, Indonesia, Japan, Korea, Malaysia, Philippines, Singapore, Thailand, and Taiwan in 1998. On average, $38.7 \%$ of firms in the study with controlling shareholders have a pyramid structure (Indonesia $66.9 \%$, Korea $42.6 \%$, and Thailand $12.7 \%$ ). They define a controlling shareholder as a shareholder with voting rights of more than $20 \% .10 .1 \%$ of the firms with controlling shareholders have crossholdings. Firms with only one controlling shareholder (having no second-largest shareholder holding more than $10 \%$ of shares) account for $67.8 \%$ on average (Japan $87.2 \%$, Korea $76.7 \%$, and Philippines $35.8 \%$ ). Cases where the controlling family directly participates in management (CEO, Chairman of the Board, or Vice-Chairman) account for $57.1 \%$ (Malaysia $85 \%$. Korea $80.7 \%$, and Japan $37.2 \%)$.

Mueller and Philippon (2008) suggest theory and empirical analysis on the determinants of family control. Family firms are efficient in dealing with hostile labor relations, so that they are more likely to appear in countries where labor-management relations are antagonistic. Family firms tend to have a paternalistic labor-management culture because of the following: (1) the controlling family of the firm tends to have a long-term perspective, and (2) since the controlling family is interested in the stability of the firm, there is an alignment of interest for both sides. For instance, in France, family firms offer better employment insurance compared to firms with a dispersed structure. They provide empirical evidence suggesting that the more hostile the labor-management relations of a country, the larger the ratio of family firms. Thus, the argument to associate the presence of family firms with weak protection for minority shareholders may only explain part of the phenomenon.

Santos and Rumble (2006) analyze how 71 bank holding companies among the top 100 (by asset size as of 2000) invest in U.S. S\&P 500 firms. The holding companies invest in stocks of 5,513 corporations through trusts, of which 4,641 are non-financial. 403 among 4,614 non-financial firms are in the S\&P 500, of which 407 firms are non-financial in the year 2000. Bank holding companies invest $86 \%$ of trust assets in stock. They hold more than 
$5 \%$ of ownership for 44 firms in S\&P 500 and more than 10\% of ownership for 12 firms. On average, they hold $12 \%$ of stocks and $10 \%$ of voting rights from S\&P 500 corporations, $12 \%$ of stocks and $10 \%$ of voting rights from major corporations (185 firms with assets over $\$ 10$ billion), and $5 \%$ of stocks and $4 \%$ of voting rights from total non-financial firms through trust. Santos and Rumble analyze ownership and control rights for non-financial firms by bank holding companies only through trusts. Thus, if we consider direct ownership and ownership through other channels, this proportion would be even higher. They also find that the greater the voting rights the bank holding company has, the higher the probability that management of the holding company acts as an outside director of the invested firms. Overall, despite the strict separation policy in the United States that prevents bank holding companies from holding more than $5 \%$ of voting shares of non-bank firms, banks exercise dominance over non-financial firms by holding a considerable amount of voting rights and putting their management as outside directors of firms in which they invest.

Gorton and Schmid (2000) study the relationship between ownership structure and performance of firms in Germany. Their sample includes 283 firms in 1975 and 280 in 1986. As we can see in Table 3, the proportion of non-financial firms as ultimate owners is quite high, as well as the proportion of these non-financial firms as the only ultimate owner. However, most of the firms have voting restrictions. Even though one holds many shares, he or she can only exercise voting rights of up to $5 \%$ or $10 \%$. Proxy voting by banks representing minority shareholders is an exception of the restriction, which makes the bank's control power stronger (see Table 4).

Table 3. Corporate Governance of German Corporations

\begin{tabular}{lcc}
\hline & 1975 & 1986 \\
\hline With Ultimate Owner & $84 \%$ & $81 \%$ \\
\hline & Form of Ulimate Owner & \\
\hline Bank (domestic or foreign) & $29 \%$ & $22 \%$ \\
\hline Insurance institution & $6 \%$ & $6 \%$ \\
\hline Family and Family Trust & $20 \%$ & $28 \%$ \\
\hline Non-financial firm & $45 \%$ & $44 \%$ \\
\hline
\end{tabular}

NOTE: With ultimate owner refers to the proportion of firms with an ultimate owner. Ultimate owner is a shareholder with voting rights of more than $20 \%$.

Table 4. How Universal. Banking; of Germany Exercise Control.

\begin{tabular}{lcl}
\hline & 1975 & 1986 \\
\hline Voting rights through stock holding & $8 \%$ & $13 \%$ \\
\hline Proxy voting & $21 \%$ & $23 \%$ \\
\hline
\end{tabular}


Various theories analyze how a bank's control influences the performance of firms. It is possible that performance is positively influenced as the interest of banks and the firm's shareholders are similar. However, it is also possible that banks gain monopoly profits by abusing their position as a controlling shareholder in a situation where capital markets are not competitive. This leads to a negative effect on performance. Of course, the two effects described above are likely to be mixed. Proxy voting allows for a deviation from the onc share-one vote principle, so that the effect of proxy voting on performance would be similar to that of a deviation from the one share-one vote principle. Gorton and Schmid (2000) provide evidence that (1) the bank's control over firms through stockholding positively affects performance, (2) the positive influence is larger than what non-financial controlling shareholders can generate, and (3) proxy voting does not affect performance.

\section{Deviation from the One Share-One Vote Principle}

It has been argued that voting rights or control rights should be given based on the number of shares as shareholders are those most interested in maximizing corporate value. This is based on the logic that shareholders are the only residual claimants. As follows, voting rights need to be proportional to the number of shares in light of economic incentives. To this point, Kaplan and Stromberg (2003) and Pagano and Volpin (2005) provide insightful evidence. However, such arguments are now under debate. Allen (2005). Allen and Gale (2000, 2002), and Allen, Carletti, and Marquez (2006) argue that other stakeholders should also have control rights because shareholders are not the only residual claimants. Giving control rights only to shareholders, and not to other residual claimants, may not maximize corporate value.

Most family firms show deviations, like a pyramid structure. Adarns and Ferreira (2007) analyze the costs and benefits of deviating from the one share-one vote principle and argue that such deviations can distort investment decisions. For example, exercising more control rights than cash-flow rights may lead to investment decisions that reduce shareholder value, such as tunneling and mutual equity investment. Through relations with affiliates, family firms may try to secure a monopoly position. Also, there may be instances of inefficient perk consumption and excessive management compensation.

On the other hand, potential benefits of the one share-one vote principle deviation may also exist. Khanna and Yafeh $(2005 ; 2007)$ argue that business groups address underdeveloped external systems by developing internal capital and labor markets and share risk within group. This leads business groups to deviate from the one share-one vote principle through pyramid structures and mutual investment.

Claessens, Djankov, Fan, and Lang (2002) analyze the correlation between 
the one share-one vote principle deviation and the market value of a firm. They analyze ownership structures of 1,301 firms-excluding financial firms and those in regulated industries-from Hong Kong, Indonesia, Korea, Malaysia, Philippines, Singapore, Thailand, and Taiwan in 1996. They find that the higher the share of large shareholders' cash-flow rights, the higher the corporate values become via incentive effects.

Several studies analyze the choice between pyramidal versus horizontal structures within business groups. Prior explanations attribute pyramid structures to exercising powerful control with small cash flow rights. However, Almeida and Wolfenzon (2006) show that even when business groups can achieve deviations from the one share-one vote principle through other schemes such as dual-class shares, pyramid structures appear widely in Europe and Asia. They infer that if the external capital market is not developed or investor protection laws are weak, pyramid structures becomes optimal in facilitating internal financing.

\section{CONTROL STRUCTURE AND SUCCESSION IN FAMILY FIRMS}

\section{Control Structure of Family Firms}

Gadhoum et al. (2005) analyze control structures of listed companies (both family and non-family firms) in the United States with a focus on the one share-one vote principle. Although they analyze 3,607 family and non-family firms, most samples relating to the deviation of the one share-one vote principle are family firms. The results are shown in Table 5.

TABle 5. Analysis OF THE DeVIation OF OWNERSHIP AND CONTROL IN THE United States, Asta, AND Europe

\begin{tabular}{lccc}
\hline & United States & Asia & Europe \\
\hline Pyramid & $8.46 \%$ & $45.68 \%$ & $22.43 \%$ \\
\hline Multiple control chain & $1.15 \%$ & $11.02 \%$ & $6.69 \%$ \\
\hline Multiple class share & $8.19 \%$ & $\mathrm{n} / \mathrm{a}$ & $19.91 \%$ \\
\hline
\end{tabular}

NOTE: Pyramid refers to the proportion of firms with a pyramid structure; multiple control chain refers to the proportion of firms with multiple control chain; and multiple class share refers to the proportion of firms with multiple class share.

In the United States, the proportion of firms which deviate from the one share-one vote principle by multiple class shares is $8.19 \%$ (Europe 19.91\%) and $8.46 \%$ by pyramid (Asia $45.68 \%$, Europe $22.43 \%$ ). One of the reasons that pyramid structures are rare in the United States is the tax imposed on inter-corporate dividends. $13.55 \%$ of U.S. firms are controlled through family 
trusts. Since many family entrepreneurs manage their assets through various trusts under different names, the actual number of family firms may increase in reality. In a separate study, Faccio and Lang (2002) analyze control structures of 2,332 family firms in Europe and find that among them, $17.61 \%$ exhibit dual-class shares, $13.81 \%$ for pyramid, and $3.22 \%$ for multiple control chains.

Several empirical studies show that the deviation of ownership and control affects corporate value in family firms. See Joh (2003) for Korea, Claessens et al. (2002) for East-Asia, Bennedsen, Morten, and Nielsen (2005) for WesternEurope, Villalonga and Amit (2006b) for the United States, and Barontini and Caprio (2006) for Continental Europe.

Villalonga and Amit (2006a) analyze the control structure in 3.006 firm-year observations of 515 firms from the Fortune 500 in 1994-2000. $40 \%$ of the sample firms are family firms where control is centered on the founder or the founder's family. The study defines family firms as those where the founder or his/her family are in positions of management, serving as directors, or are controlling shareholders. $40 \%$ of all samples are family firms. Among family firms, $46 \%$ are founder-controlled firms, while $54 \%$ are controlled by the founder's family. In comparing family firms and non-family firms, the study finds that family firms appear to perform better than non-family firms, although this stems from the better performance of founder-controlling firms. The performance of family firms (Tobin's Q) is higher than that of non-family firms at a $10 \%$ significant level, with the size difference between family and non-family firms being statistically insignificant. Non-family firms are older than family firms. Family firms were found to grow faster and have higher market return, while also exhibiting higher capital expenditure and smaller leverage. They also find that the founder or family holds $15.3 \%$ of shares and $18.8 \%$ of voting rights. On the flipside, non-family block-holders hold $16.2 \%$ of shares and $13.2 \%$ of voting rights.

Villalonga and Amit (2006a) also find that pyramid structures and voting agreements positively affect the market value of a firm, while dual-class shares have a negative effect. Bennedsen, Morten, and Nielsen (2005) show that dual class shares have a larger and more significant negative effect on firm value than pyramids and crossholdings in Western-European family firms. Gompers, Ishii, and Metrick (2010) only analyze dual-class firms in the United States and find that insiders' cash-flow rights are positively associated with firm value while voting rights are negatively associated.

In the United States, control-enhancing mechanisms can be classified into four categories: (1) dual-class shares, (2) voting agreements, (3) pyramids, and (4) disproportional board representation (see Table 6). Among these categories, firms exhibiting disproportional board representation totaled $66 \%$, dual-class shares $21 \%$, voting agreements $7 \%$, and pyramids $6 \%$. Overall, control rights are 1.28 times larger than cash-flow rights, with this level being 1.34 in East 
Asia and 1.15 in Western Europe. The influence on director selection can deviate from control and ownership. Since this mechanism is not considered in the ratio above, we can say that deviation in U.S. family firms is much larger. This also means potential conflicts between the controlling and minor shareholder is not less than European or Asian firms. Deviation of ownership and control is the largest when dual-class shares are used (2.55 times). While founders often control firms with dual-class shares to facilitate succession, there are vilier control-enhancing mechanisms. Family members occupy $17.3 \%$ of total director positions and serve as the CEO of $51 \%$ of the sample firms. Family members also serve as the CEO or Chairman of the Board in $59 \%$ of the sample firms (Villalonga and Amit 2006b).

\section{Tabie 6. Cases of Control-Enhancing mechanisms of U.S. Family firms}

\begin{tabular}{|c|c|}
\hline $\begin{array}{l}\text { Category of control- } \\
\text { enhancing mechanisms }\end{array}$ & Cases of U.S. family firms \\
\hline Dual-Class Share & $\begin{array}{l}\text { In the case of Camcas, Ralph Robert, the founder, and Brian } \\
\text { Robert. his son. have } 3.14 \% \text { of all shares and hold } 85.64 \% \\
\text { of voting rights. } \\
\text { - Viacom, Tyson foods, Ford motors, ete. have dual-class shares. }\end{array}$ \\
\hline Voting agreements & $\begin{array}{l}\text { Katharine Graham of the Washington Post and her } 4 \text { children } \\
\text { have } 44.9 \% \text { of voting rights } \rightarrow \text { Berkshire Hathaway had } 18.3 \% \\
\text { of voting rights } \rightarrow \text { Berkshire Hathaway delegated their voting rights } \\
\text { to Donald Graham, the son of Katharine Graham. As a result, } \\
\text { they hold } 63.2 \% \text { of voting rights. }\end{array}$ \\
\hline Pyramid & $\begin{array}{l}\text { The Tisch brothers hold } 32 \% \text { of the stocks of Loews } \rightarrow \text { Loews } \\
\text { holds } 100 \% \text { of stocks of LT holding } \rightarrow \text { LT holding holds } 17.63 \% \\
\text { of stocks of CBS. As a result, the Tisch brothers hold } 5.64 \% \\
(32 \% * 17.63 \% \text { ) of stocks of CBS, but hold } 17.63 \% \text { ( }=\min (32 \% \text {, } \\
17.63 \%) \text { ) of voting rights } \rightarrow \text { CBS is controlled by the Tisch brochers } \\
\text { through a pyramid structure. }\end{array}$ \\
\hline $\begin{array}{l}\text { Disproportion Board } \\
\text { Representation }\end{array}$ & $\begin{array}{l}\text { In the case of the New York Times, they have two kinds of Common } \\
\text { stock (Class A and Class B), and Class A accounts for } 99.56 \% \\
\text { and Class B accounts for } 0.44 \% \rightarrow \text { A shareholder of Class A stock } \\
\text { can elect } 5 \text { directors out of } 15 \text { and a shareholder of Class B stock } \\
\text { can elect } 10 \text { directors } \rightarrow \text { The Ochs Sulzberger family hold } 17.9 \% \\
\text { of shares } \rightarrow \text { However, since they hold } 88.7 \% \text { of Class-B stock, } \\
\text { they have election rights for } 66.7 \% \text { of directors. }\end{array}$ \\
\hline
\end{tabular}

NOTE: In the United States, control-enhancing mechanisms can be classified into fout categories: (1) dual-class shares, (2) voting agreements, (3) pyramids, and (4) disproportional board representation.

\section{Succession of Control}

There also exists debate on the succession of control within family firms. Owner 
families may have a longer-term perspective if they serve as managers, and controlling families may also be able to reduce agency costs. Also, collaboration and knowledge transfer between family members are potentially easier (Jensen and Meckling 1976; Grossman and Hart 1988; Mucller and Philippon 2008). On the other hand, managers selected from within the small family pool may be inferior to professional managers chosen from the market (Morck, Stangeland, and Yeung 2000). Burkart, Panunzi, and Shleifer (2003) suggest a theory about family firm structure and control succession. They assume that a current founder is the controlling shareholder and manager, and that professional management is better skilled than family members. If investor protection by law is powerful, founders prefer a dispersed ownership/control structure and professional management. If investor protection by law is moderate, founders prefer professional management, but have an incentive to remain as major shareholders and monitor management. If investor protection by law is weak, founders pass on control to their family.

Villalonga and Amic (2006b) analyze how family firm performance varies as family members own, manage, or control the firm. Their data set includes 2,808 firm-year observations of 508 firms from the Fortune 500 in 1994-2000. When a founder works as CEO or chairman with a professional CEO, this positively affects the market value of a firm. When the family firm is managed by the family successor and not by the founder, corporate value is negatively influenced. The effect is negative even in cases where the founder works as a chairman. The negative effect of the successor is driven by the second generation, while a third generation CEO has no influence and a fourth generation CEO positively influences firm value.

Francisco Perez-Gonzalez (2006) analyzes how succession of control affects firm performance. His data set includes 335 control succession cases in U.S. firms, of which 122 are among family members and 213 are cases of non-family succession. Succession to family members who are well-educated in prestigious universities was not shown to have an influence on corporate performance, but succession to family members who are not well-educated in prestigious universities negatively influenced corporate performance.

\section{BUSINESS GROUPS}

Business groups are groups of legally independent firms connected through stocks or family. It is difficult to assess whether business groups wield a positive or negative influence on the economy. Khanna and Yafeh $(2005 ; 2007)$ analyze business groups in emerging markets where many business groups operate. Business groups may be a popular form in the country where market systems are underdeveloped. Business groups replace underdeveloped capital and labor markets 
by forming internal capital and labor markets (Hubbard, Glenn, and Palia 1999; Mourer and Haber 2006). Khanna and Yafeh (2005; 2007) also argue that within business groups, firms can share management ability, technology, and reduce risk through industrial diversification. Cases in Korea, Taiwan, and Thailand exhibit risk sharing among firms within business groups. However, there may be instances of tunneling, empire building by management, risk evasion, and inefficient resuurce allocation (see Scharfscein and Stein (2000) and Maksimovic and Phillips (2002) for inefficient resource allocation).

Thus, two opposing results exist as to whether diversification creates value or not (i.e., diversification premium versus discount). Results of U.S. firms generally point to a discount, but this negative influence exists only in developed countries with advanced capital markets. In the case of the United States, diversification was prevalent until the 1980 s, but after the 1990 s, a refocusing strategy became popular. Conversely, studies indicate a positive influence of diversification in underdeveloped countries (Fauver, Houston, and Naranjo 2003).

Tabie 7. Cases and Effects of Financial. Business ani) Reiated lending WITHIN BISINFSS GROTPS

\begin{tabular}{|c|c|}
\hline $\begin{array}{l}\text { Financial business } \\
\text { within business } \\
\text { groups }\end{array}$ & $\begin{array}{l}\text { UK Multinational Business Groups operated financial businesses } \\
\text { extensively in the early 20th century. } \\
\text { " Business Groups in Chile operated financial businesses in the } 1980 \text { s } \\
\text { when financial business was not developed. } \\
\text { Almost every bank in Turkey is Group-affiliated. } \\
\text { - Large Business Groups in Indonesia uses financial affiliates when } \\
\text { capital demand increases to stare a new business. }\end{array}$ \\
\hline $\begin{array}{l}\text { Positive and negative } \\
\text { effects of related } \\
\text { Lending within } \\
\text { business groups }\end{array}$ & $\begin{array}{l}\text { Mourer and Haber (2006) showed positive effects of Related Lending } \\
\text { using data from Mexican Business Groups in 1888-1993: No negative } \\
\text { effects of Related Lending (tunneling and inefficient allocation of } \\
\text { resources) exist but rather firms which received Related Lending } \\
\text { show better performance compared to comperitors. } \\
\text { - La Porta et al. (2003) showed that the defaule rate of Related Lending } \\
\text { is } 33 \% \text { higher than non-related lending using data on Mexico in } \\
\text { the } 1990 \text { s. }\end{array}$ \\
\hline
\end{tabular}

With respect to Korean business groups, debates exist within the literature about the impact of diversification strategies. Positive results regarding diversification appear in studies by Chang and Choi (1988) (low transaction cost), Chang and Hong (2000) (sharing resources), Chang and Hong (2002) (replacement of inefficient external markets), and Kim (2006) (superior productivity). Negative results appear in Shin and Park (1999) (inefficient resource allocation), Bae, Kang and Kim (2002) (tunneling by issuing convertible bonds), Campbell and Keys (2003), Joh (2003) (tunneling by pyramid), Ferris, Kim, and Kitsabunnarat 
(2003) (over-investment, cross-subsidization), and Baek, Jang and Lee (2006) (tunneling by issuing bonds with warrants). These mixed results are commented on by Lee, Peng, and Lee (2001), with the study arguing that diversification of business groups had a positive influence until the early 1990s, but exhibited a negative influence after 1994.

Table 7 shows cases and the effects of financial business and related lending within business groups. Many business groups have financial business and conduct related lending. Hoshi, Kashyap, and Scharfstein (1991) and Aoki, Patrick and Sheard (1994) argue that related lending could improve efficiency by monitoring insiders by insiders. Rajan (1992) suggests that inside bankers may be able to force inside borrowers not to implement bad projects in advance with the use of precise information. However, problems of looting and tunneling could take place. For instance, if the bank is protected by a deposit insurance, the controlling shareholder of the bank simply makes loans to affiliates on lower terms compared to market rates. See Kane (1989) for the United States, Kang and Stulz (1997), Morck and Nakamura (1999) for Japan, Demirgüç-Kunt and Detraiache (2000) for a cross-country sample, and Gil-Díaz (2000) for Mexico.

\section{CONCLUSION}

This paper investigates the implications of family firms and business groups. Family firms exist not only in developing markets, but are also prevalent in developed markets. Corporate governance is an important determinant of the value of family firms and business groups in most countries and cases. Research about corporate governance of family firms and business groups provide large implications for Korean firms. We first presented major issues on corporate governance in chaebols. Then, we grouped studies in accordance to those issues: existence of controlling shareholder, deviation from the one share-one vote principle, family members' participation in management, succession of control to family members, and the relationship between financial and industrial capital within business groups. Many factors in corporate governance influence the value of family firms and business groups in a nuanced manner. Almost all corporate governance practices create both positive and negative effects to the value of family firms and business groups, with little consensus about which effect is larger. Also, it is possible that corporate governance of family firms and business groups has been optimally determined under different circumstances across countries.

In sum, despite much literature in this field, little academic consensus arises yet about policy and managerial frameworks. Corporate governance reform is an even more difficult agenda in many cases. The pros and cons of family business groups highly depend on the social and historical contexts as well. 
Therefore, it would be very risky to apply one practice of corporate governance in different situations, and there is no definitive answer about what constitutes good corporate governance to family business groups.

Future research requires interdisciplinary approaches which touch on aspects of law, sociology, politics and economics to establish a useful framework about family business groups for policy makers and pracrical managers. Therefore, there is a need to use multiple research methods including qualitative studies and case studies to create proper governance systems and frameworks. Overall, this review should help to clarify apparent differences in the literature, while pointing to further avenues of investigation.

\section{REFERENCES}

Adams, R. and D. Ferreira, 2007. One Share-One Vote: The Empirical Evidence. ECGI Working Paper.

Admati, A., P. Pfleiderer, and J. Zechner. 1994. Large Shareholder Activism, Risk Sharing, and Financial Market Equilibrium. Journal of Political Economy 102: $1097-1130$.

Almeida, H. V. and D. Wolfenzon. 2006. A Theory of Pyramidal Ownership and Family Business Groups. The Journal of Finance 61: 2637-2680.

Allen, F. 2005. Corporate Governance in Emerging Markets. Oxford Review of Economic Policy 21: 164-177.

Allen, F. and D. Gale. 2000. Comparing Financial Systems. Cambridge, MA: MIT Press.

Allen, F, and D. Gale. 2002. A Comparative Theory of Corporate Governance. Wharton Financial Institutions Center. Working Paper \# 03-27.

Allen, F., E. Carletti, and R. Marquez. 2006. Stakeholder Capitalism, Corporate Governance and Firm Value. Working Paper. University of Pennsylvania. Amsden, A. H. 1989. Asia's next giant. Oxford University Press.

Anderson, R. and D. M. Reeb. 2003. Founding family ownership and firm performance: Evidence from the S\&P 500. Journal of Finance 58: 1301-1329. Aoki, M., H. Patrick, and P. Sheard. 1994. The Japanese Main Banking System: An Introductory Overview. In The Japanese Main Banking System, eds. Masahiko Aoki and Hugh Patrick, 3-50. Oxford, UK: Oxford University Press.

Bae, K.-H., J.-K. Kang, and J.-M. Kim. 2002. Tunneling or Value Added? Evidence from Mergers by Korean Business Groups. Journal of Finance 57(6): 2695-2740.

Baek, J.-S., J.-K. Kang, and I. Lee. 2006. Business Groups and Tunneling: Evidence from Private Securities Offerings by Korean Chaebols. Journal of Finance 61(5): 2415-2449.

Barontini, R. and L. Caprio. 2006. The effect of family control on firm value 
and performance: Evidence from continental Europe. European Financial Management 12: 689-723.

Bennedsen, M. and K. Nielsen, 2005. The principle of proportionality: Separating the impact of dual class shares, pyramids, and cross-ownership on firm value across legal regimes in Western Europe. Working Paper. Copenhagen Business School.

Berie, A. and G. Méans. 1932. The Mudern Corpuration and Private Property. New York: Macmillan.

Bertrand, M., P. Mehta, and S. Mullainathan. 2002. Ferreting out tunneling: An application to Indian business groups. Quarterly Journal of Economics 117: 1047-1073.

Burkart, M., F. Panunzi, and A. Shleifer. 2003. Family Firms. Journal of Finance 58(5): 2167-2202.

Burkart, M. and S. Lee. 2007. The One Share-One Vote Debate: A Theoretical Perspective. ECGI Working Paper.

Buysschaert, A., M. Deloof, and M. Jegers. 2004. Equity Sales in Belgian Corporate Groups: Expropriation of Minority Shareholders? A Clinical Study. Journal of Corporate Finance 10(1): 81-103.

Campbell, T. and P. Keys, 2003. Corporate Governance in South Korea: The chaebol Experience. Journal of Corporate Finance 57: 1731-1762.

Chang, S. and U. Choi. 1988. Structure, Strategy and Performance of Korean Business Groups: A Transaction Cost Approach. Journal of Industrial Economics 37: $141-158$.

Chang. S. and J. Hong. 2000. Economic Performance of Group Affiliated Companies in Korea: Intra-Group Resource Sharing and Internal Business Transaction. Academy of Management Journal 43: 429-448.

Chang, S. and J. Hong. 2002 How Much Does the Business Group Matter in Korea? Strategic Management Journal 23: 265-274.

Chang, S. 2003. Ownership Structure, Expropriation, and Performance of Group-Affiliated Companies in Korea. Academy of Management Jounal 46(2): 238-253.

Chang, J. J. and H.-H. Shin. 2005. Does the Family Portfolio Perform Better than the Group Portfolio? Evidence from Korean Conglomerates. Unpublished.

Claessens, S., S. Djankov, and L. H. P. Lang. 2000. The Separation of Ownership and Control in East Asian Corporations. Journal of Financial Economics 58: 81-112.

Claessens, S., S. Djankov, J. P. H. Fan, and L. H. P. Lang. 2002. Disentangling the incentive and Entrenchment Effects of Large Shareholdings. Journal of Finance 57: 2741-2771.

Demirgüç-Kunt, A. and E. Detragiache. 2000. Does Deposit Insurance Increase Banking Stability? An Empirical Investigation. World Bank Mimeo.

Faccio, M. and L. H. P. Lang. 2002. The Ultimate Ownership of Western 
European Corporations. Journal of Financial Economics 65: 365-395.

Fauver, L., J. Houston, and A. Naranjo. 2003. Capital Market Development, International Integration, Legal Systems, and the Value of Corporate Diversification: A Cross-Country Analysis. Jounal of Financial and Quantitative Analysis 38(1): 135-157.

Ferris, S., K. Kim, and P. Kitsabunnart. 2003. The Cost (and Benefit) of Diversified Busincss Groups: The Case of Korean chaebols. Jommal of Ranking and Finance 27: 251-273.

Fogel, K. 2006. Oligarchic Family Control, Social Economic Outcomes, and the Quality of Government. Joumal of International Business Studies 37(5): 603-622.

Gadhoum, Y., L. H. P. Lang, and L. Young. 2005. Who controls US? European Financial Management 11: 339-363.

Gil-Díaz, F. 2000. The China Syndrome or the Tequila Crisis, draft prepared for the Conference on Fiscal and Financial Reforms in Latin America, Stanford University.

Gompers, P. A., J. Ishii, and A. Metrick. 2010. Extreme governance: An Analysis of dual-class firms in the United States. Retiew of Financial Studies 23: 1051-1088.

Gorton, G. and F. Schmid. 2000. Universal Banking and the Performance of German Firms. Jounal of Financial Economics 58: 29-80.

Grossman. S. J and O. D. Hart. 1988. One Share-One Vote, and the Market for Corporate Control. Journal of Financial Economics 20: 175-202.

Guillén, M. F. 2000. Business Groups in Emerging Economies: A Resource-Based View. Academy of Management Journal 43(3): 362-380.

Hoshi, T., A. Kashyap, and D. Scharfstein. 1991. Corporate Structure, Liquidity, and Investment: Evidence from Japanese Industrial Groups. Quarterly Journal of Economicis 106: 33-60.

Hubbard, R. G. and D. Palia. 1999. A Reexamination of the Conglomerate Merger Wave in the 1960s: An Internal Capital Markets View. Journal of Finance 54(3): 113-152.

Huddart, S. 1993. The Effect of a Large Sharcholder on Corporate Value. Management Sience 39: 1407-1421.

Jensen, M. C. and W. H. Meckling. 1976. Theory of the firm: Managerial behavior, agency costs and ownership structure. Journal of Financial Economics 3: $305-360$.

Joh, S. W. 2003. Corporate Governance and Firm Profitability: Evidence from Korea before the Economic Crisis. Joumal of Financial Economics 68(2): 287-322. Johnson, S., R. L. Porta, F. Lopez-de-Silanes, and A. Shleifer. 2000. Tunneling. American Economic Review Papers and Proceedings 90: 22-27.

Kane, E. J. 1989. The S\&L Insurance Mess: How did it Happen? Washington, D.C.: The Urban Institute Press.

Kaplan, S. and P. Stromberg. 2003. Financial Contracting Theory Meets the Real World: Evidence from Venture Capital Contracts. Review of Economic Studies 
70: $281-315$.

Khanna, T. and Y. Yafeh. 2005. Business Groups and Risk Sharing around the World. Journal of Business 78(1): 301-340.

Khanna, T. and Y. Yafeh. 2007. Business groups in emerging markets: Paragons or parasites? Journal of Economic Literature 45: 331-372.

Kim, E. 2006. The Impact of Family Ownership and Capital Structures on Productivity Performance of Korean Manufacturing Firms: Curporate Governance and the Chaebol Problem. Journal of the Japanese and International Economies 20(2): 209-233.

Kroszner, R. and P. Strahan. 2001. Bankers on the Boards: Monitoring, Conflicts of Interest, and Lender Liability. Journal of Financial Economics 62(3): 415-452.

La P., Rafael, F. Lopez-de-Silanes, A. Shleifer, and R. W. Vishny. 1998. Law and Finance. Journal of Political Economy 106: 1113-1155.

La P., Rafael, F. Lopez-de-Silanes, and A. Shleifer. 1999. Corporate ownership around the world. Journal of Finance 54: 471-517.

La P., Rafael, F. Lopez-de-Silanes, A. Shleifer, and R. W. Vishny. 2002. Investor protection and corporate valuation. Journal of Finance 57: 1147-1170.

La P., Rafael, F. Lopez-de-Silanes, and G. Zamarripa. 2003. Related Lending, Quarterly Journal of Economics 118(1): 231-268.

Lee, K., M. Peng, and K. Lee, 2001. Institutions and Changing Performance of Corporate Groups: The Case of the chaebols in Korea. Unpublished.

Maksimovic, V. and G. Phillips. 2002. Do Conglomerate Firms Allocate Resources Inefficiently across Industries? Theory and Evidence. Journal of Finance 57(2): 721-767.

Maug, E. 1998. Large Shareholders as Monitors: Is There a Trade-off between Liquidity and Control? Journal of Finance 53: 65-98.

Maurer, N. and S. Haber. 2006. Related Lending and Economic Performance: Evidence from Mexico, 1888-1913, Unpublished.

Morck, R. and M. Nakamura. 1999. Banks and Corporate Control in Japan. Journal of Finance 54: 319-339.

Morck, R., D. Stangeland, and B. Yeung. 2000. Inherited wealth, corporate control and economic growth: The Canadian disease. In Concentrated Corporate Ownership, ed. Randall K. Morck. Chicago, IL: University of Chicago Press.

Mueller, H. M. and T. Philippon. 2008. Family Firms, Paternalism, and Labor Relations. ECGI Finance Working Paper \# 186/2007.

Noe, T. 1997. Institutional Activism and Financial Market Structure. Tulane University Working Paper.

Pagano, M. and P. Volpin. 2005. Managers, workers, and corporate control. Journal of Finance 60: 841-868.

Pérez-González, F. 2006. Inherited Control and Firm Performance. American Economic Review 96(5): 1559-1588.

Rajan, R. 1992. Insiders and Outsiders: The Choice Between Informed and 
Arm's Length Debt. Journal of Finance 47: 1367-1400.

Santos, J. A. C. and A. S. Rumble. The American keiretsu and universal banks: Investing, voting and sitting on nonfinancials' corporate boards. Journal of Financial Economics 80(2): 419-454.

Scharfstein, D. S. and J. C. Stein. 2000. The Dark Side of Internal Capital Markets: Divisional Rent-Seeking and Inefficient Investment. Journal of Finance 55(6): $2537-2564$.

Shleifer, A. and R. Vishny. 1986. Large Shareholders and Corporate Control. Journal of Political Economy 94: 461-488.

Shin, H.-H. and Y. S. Park. 1999. Financing Constraints and Internal Capital Markets: Evidence from Korean chaebols. Journal of Corporate Finance 5(2): 169-191.

Villalonga, B. and R. Amit. 2006a. Benefits and Costs of Control-Enhancing Mechanisms in US Family Firms. ECGI Working Paper \# 131/2006.

Villalonga, B. and R. Amit. 2006b. How do family ownership, control, and management affect firm value. Journal of Financial Economics 80: 385-417. 